\title{
Kualitas Fisik Wafer Turiang Padi yang Dicampur dengan Rumput Lapang
}

\author{
R. Z. Islami ${ }^{1 \text { a }}$, S. Nurjannah ${ }^{2}$, I. Susilawati ${ }^{3}$, H. K. Mustafa ${ }^{3}$, A. Rochana $^{3}$ \\ ${ }^{1}$ Mahasiswa Pascasarjana Fakultas Peternakan, Universitas Padjadjaran \\ ${ }^{2}$ Program Studi Peternakan, Fakultas Pertanian, Universitas Bandung Raya \\ ${ }^{3}$ Fakultas Peternakan, Universitas Padjadjaran \\ ${ }^{a}$ Email: romi.zamhir@unpad.ac.id
}

\begin{abstract}
Abstrak
Penelitian bertujuan untuk mengkaji kualitas fisik wafer turiang padi (WTP). Turiang merupakan hasil ikutan tanaman padi generasi kedua dengan kandungan nutrisi yang lebih tinggi dibandingkan jerami padi. Rancangan yang digunakan adalah RAL dengan empat perlakuan (P1 : Turiang 100\% + rumput lapang $0 \%$; P2 : Turiang 75\% + rumput lapang 25\%; P3 : Turiang $50 \%$ + rumput lapang $50 \%$; dan P4 : Turiang $25 \%$ + rumput lapang $75 \%$ ) dan enam ulangan. Peubah yang diamati meliputi kualitas fisik WTP dan data yang diperoleh dianalisis statistik dengan ANOVA dan Uji lanjut Duncan. Hasil menunjukkan pembuatan WTP yang dicampur dengan rumput lapang nyata $(\mathrm{P}<0,05)$ mempengaruhi kualitas fisik WTP. Rataan tertinggi pada KA diperoleh perlakuan P2 (10,37\%), BJ diperoleh perlakuan P4 $(0,84)$, Kerapatan diperoleh perlakuan P3 $(0,083 \mathrm{~g} / \mathrm{cm})$ dan P4 $(0,083 \mathrm{~g} / \mathrm{cm})$, dan Daya Serap Air diperoleh perlakuan P3 (205,24\%), sedangkan nilai terendah dari semua peubah yang diamati diperoleh perlakuan P1 dengan nilai berturut-turut KA (P1 9,65\% dan P4 9,30\%), BJ (0,67), Kerapatan $(0,072$ $\mathrm{g} / \mathrm{cm})$, dan Daya Serap Air (175,52\%).
\end{abstract}

Kata kunci: turiang, wafer, kualitas fisik

\section{Physical Quality of Ratoon-Wafer Mixed with Field Grass}

\begin{abstract}
The aim of this research was to know physical quality of ratoon wafer. Ratoon is a by-product of second generation rice plants with higher nutrient content than rice straw. The method used was experimental by using Completely Randomized Design (CRD) with four treatment (P1: Ratoon 100\% + field grass $0 \%$; P2 : Ratoon $75 \%+$ field grass 25\%; P3 : Ratoon $50 \%+$ field grass $50 \%$; dan P4: Ratoon $25 \%$ + field grass $75 \%$ ) and six replication. The observed variable were physical quality and the data were analyzed by variance (ANNOVA) method and continued with the Duncan's Multiple Range Test. The results showed that the making of ratoon wafer mixed with field grass had an effect $(P<0.05)$ on the physical quality of WTP. The highest value of $K A$ rate was $P 2(10,37 \%)$, spesific gravity rate was $P 4$ $(0,84)$, density rate was $P 3(0,083 \mathrm{~g} / \mathrm{cm})$ and $P 4(0,083 \mathrm{~g} / \mathrm{cm})$, and water absorption rate was $P 3$ (205,24\%), while the lowest value of all variable observed P1 with value KA (P1 9,65\% and P4 9,30\%), spesific gravity $(0,67)$, density $(0,072 \mathrm{~g} / \mathrm{cm}$, and water absorption $(175,52 \%)$.
\end{abstract}

Keywords: ratoon, wafer, physical quality

\section{Pendahuluan}

Melimpahnya hasil ikutan/limbah pertanian pada saat musim panen atau musim penghujan menyebabkan banyaknya bahan yang tidak termanfaatkan dan akan terbuang begitu saja, sementara disisi lain hasil ikutan/limbah pertanian dapat dijadikan sebagai salah satu pakan ternak. Pakan merupakan segala sesuatu yang dapat dimakan dan dicerna oleh ternak tanpa menimbulkan racun. Pakan akan sulit didapatkan terutama pada saat musim kemarau, sehingga peternak/petani harus bisa memanfaatkan pakan berupa hasil ikutan/limbah pertanian yang melimpah pada saat musim panen dan penghujan. Salah satu tanaman pertanian yang dapat menghasilkan hasil ikutan ataupun limbah lainnya adalah tanaman padi. Pada saat panen bagian utama yang dimanfaatkan manusia adalah bagian bulir/padi, dan pada saat tersebut dapat menghasilkan sesuatu yang tidak termanfaatkan oleh manusia yaitu jerami padi. Disamping itu, tanaman padi juga 
menghasilkan by-product atau hasil ikutan berupa Turiang Padi.

Turiang atau singgang (bahasa jawa) atau ratun (adopsi Bahasa Inggris) padi yaitu anak tanaman padi yang tumbuh secara liar (biasanya setelah dipanen) atau sistem penanaman yang tanaman generasi keduanya berasal (tumbuh) dari perakaran tanaman generasi sebelumnya (KBBI, 2019). Secara morfologi, turiang tidak berbeda dengan tanaman utamanya, hanya saja jumlah anakan produktif lebih sedikit dan batang lebih pendek. Salah satu keuntungan turiang padi adalah memiliki nilai nutrisi yang cukup baik untuk meningkatkan produktivitas ternak.

Pada saat melimpahnya produksi turiang padi, maka salah satu upaya yang dilakukan agar turiang dapat dimanfaatkan dalam jangka panjang adalah dengan cara pengawetan menjadi wafer. Wafer merupakan salah satu cara yang digunakan untuk pengawetan tanaman atau hijauan selain hay dan silase yang dibuat dalam bentuk cube. Menurut Coleman dan Lawrence (2000) hijauan dalam bentuk wafer memiliki kelebihan dan kekurangan. Salah satu kelebihannya adalah dapat meningkatkan konsumsi pakan serta kandungan nutrien yang konsisten dan stabil, sedangkan kekurangannya adalah membutuhkan biaya tambahan yang akan mempengaruhi biaya produksi. Pengawetan dalam bentuk wafer akan memberikan kemudahan dalam pemberian pada ternak dan dalam penyimpanan. Wafer pakan dibuat dengan bantuan panas dan tekanan yang menggunakan teknik proses pembuatan pakan (Sondhy, 2010). Penelitian yang dilakukan bertujuan untuk mengkaji potensi Turiang Padi sebagai pakan ternak terutama musim kemarau yang diawetkan dengan cara dibuat wafer.

\section{Materi dan Metode Bahan}

Bahan utama yang digunakan terdiri atas turiang padi dan rumput lapang. Selain itu ada bahan tambahan lain yang digunakan pada saat pembuatan wafer yang terdiri atas air, dedak padi, molases dan urea.

\section{Metode Penelitian}

Turiang padi dikeringkan dengan sinar matahari selama 2-3 hari hingga kadar air bahan mencapai $13 \%$, lalu dicacah menggunakan mesin chopper. Cacahan turiang padi dicampur dengan bahan lain seperti air, dedak padi, molasses, dan urea. Setelah tercampur rata dilakukan pencetakan dengan ukuran $15 \times 15 \times 15$ cm dengan menggunakan mesin kempa dengan tekanan 200-300 $\mathrm{kg} \mathrm{cm}^{2}$ dan kemudian dikeringkan dengan bantuan sinar matahari. Wafer turiang diangkat lalu didinginkan yang kemudian sebagian dari wafer turiang dilakukan uji sifat fisik.

\section{Desain Penelitian}

Desain percobaan yang digunakan adalah Eksperimental dengan Rancangan Acak Lengkap, yang terdiri atas empat perlakuan yakni P1 (Turiang 100\% + rumput lapang 0\%), P2 (Turiang 75\% + rumput lapang 25\%), P3 (Turiang $50 \%+$ rumput lapang 50\%), dan P4 (Turiang 25\% + rumput lapang 75\%) dengan enam ulangan. Data diolah menggunakan ANOVA dan diuji lanjut dengan Uji Lanjut Duncan.

\section{Peubah yang Diamati}

$$
\begin{aligned}
& \text { 1. Kadar Air \% (AOAC, 1988) = } \\
& \frac{\text { berat awal }(\mathrm{g}) \text {-berat kering oven }(\mathrm{g})}{\text { berat awal }(\mathrm{g})} \times 100 \%
\end{aligned}
$$
(W : berat, P : Panjang, L : Lebar, T : Tebal) 4. Daya Serap Air $(\%)=\frac{B-A}{A} \times 100 \%$ (A : Berat sebelum direndam, $\mathrm{P}$ : Berat setelah direndam.

\section{Hasil dan Pembahasan \\ Kadar Air (KA)}

Kadar air merupakan jumlah partikel air yang tertinggal di dalam wafer yang bergantung pada penyimpanan dan kelembaban udara sekelilingnya. Pada Tabel 1 dapat dilihat bahwa hasil analisis ragam menunjukkan bahwa wafer yang dibuat memberikan pengaruh nyata $(\mathrm{P}<0,05)$ terhadap kadar air. Kadar air terendah diperoleh P1 dan P4, sedangkan tertinggi diperoleh P2 dan P3. Berdasarkan uji lanjut Duncan, P1 dan P4 menunjukkan hasil yang berbeda nyata dengan P2 dan P3. Rataan kadar air wafer penelitian menunjukkan hasil yang masih berada dibawah standar, dimana standar kadar air menurut SNI No 01-3930-1995 adalah $14 \%$.

Faktor yang mempengaruhi KA adalah penyimpanan dan kelembaban. KA akan semakin meningkat apabila wafer disimpan 
dalam kurun waktu yang cukup lama. Pomeranz (1974) menyebutkan bahwa penyimpanan yang baik adalah penyimpanan dengan kadar air di bawah 15\%. Hasil penelitian menunjukkan nilai rataan kadar air wafer $<15 \%$, hal ini dapat dikatakan WTP yang dibuat disimpan dengan baik.

Wafer yang disimpan pada tempat yang lembab akan mengalami proses penyerapan uap air yang mengakibatkan kadar airnya menjadi tinggi dan mikroorganisme seperti jamur dan bakteri akan semakin mudah untuk tumbuh dan berkembang. Apabila kadar air bahan rendah sedangkan kelembaban sekitarnya tinggi, maka akan terjadi penyerapan uap air dari udara sehingga kadar air menjadi lebih tinggi dan hal ini dapat menyebabkan penurunan kualitas pakan akibat tumbuhnya jamur atau perkembangan bakteri.

\section{Berat Jenis}

Berat jenis wafer merupakan perbandingan berat wafer terhadap volume dan merupakan salah satu penentu kerapatan tumpukan. Pada Tabel 1 dapat dilihat bahwa hasil analisis ragam menunjukkan bahwa wafer yang dibuat dengan berbagai perlakuan memberikan pengaruh nyata $(\mathrm{P}<0,05)$ terhadap berat jenis. Setelah dilakukan uji lanjut Duncan, P1 menunjukkan hasil yang berbeda nyata dengan P2, P3 dan P4. Perlakuan P2 menunjukkan hasil yang tidak berbeda nyata dengan P3, dan P3 menunjukkan hasil yang tidak berbeda nyata dengan $\mathrm{P} 4$, dengan kata lain P2 dan P3 serta P3 dan P4 menunjukkan hasil yang sama besarnya.

Wafer P4 dengan komposisi 25\% turiang dan $75 \%$ rumput lapang mempunyai berat jenis paling tinggi, sedangkan wafer P1 dengan komposisi $100 \%$ turiang mempunyai berat jenis paling rendah. Wafer yang mempunyai berat jenis besar cenderung akan mudah terpisah atau kurang merekat. Suadnyana (1998) menyatakan bahwa adanya variasi dalam nilai berat jenis dipengaruhi oleh kandungan nutrisi bahan pakan, distribusi ukuran partikel dan karakteristik ukuran partikel. Oleh karena itu, P4 akan mudah terpisah terutama pada saat adanya penanganan dan pengolahan.

Faktor lain yang berpengaruh adalah adanya perbedaan berat jenis yang cukup besar diantara partikel penyusun wafer. Dijelaskan oleh Kling dan Wohlbier (1983) bahwa ransum yang terdiri atas partikel yang memiliki perbedaan berat jenis yang besar, maka campurannya tidak akan stabil dan cenderung mudah terpisah kembali. Selain itu, wafer yang memiliki berat jenis yang tinggi akan mengakibatkan kapasitas ruang yang semakin meningkat.

Tabel 1. Kualitas Fisik Wafer Turiang Padi

\begin{tabular}{lrrrr}
\hline \multirow{2}{*}{ Peubah } & \multicolumn{5}{c}{ Perlakuan } \\
\cline { 2 - 5 } & \multicolumn{1}{c}{ P1 } & \multicolumn{1}{c}{ P2 } & \multicolumn{1}{c}{ P3 } & \multicolumn{1}{c}{ P4 } \\
\hline Kadar Air (\%) & $9,65^{\mathrm{a}} \pm 0,17$ & $10,37^{\mathrm{b}} \pm 0,44$ & $10,34^{\mathrm{b}} \pm 0,42$ & $9,30^{\mathrm{a}} \pm 0,55$ \\
Berat Jenis & $0,67^{\mathrm{a}} \pm 0,05$ & $0,75^{\mathrm{b}} \pm 0,05$ & $0,79^{\mathrm{b}} \pm 0,04$ & $0,84^{\mathrm{c}} \pm 0,07$ \\
Kerapatan (g/cm) & $0,072^{\mathrm{a}} \pm 0,002$ & $0,081^{\mathrm{ab}^{\mathrm{b}}} \pm 0,004$ & $0,083^{\mathrm{b}} \pm 0,008$ & $0,083^{\mathrm{b}} \pm 0,007$ \\
Daya Serap Air (\%) & $175,52^{\mathrm{a}} \pm 10,00$ & $192,38^{\mathrm{ab}^{\mathrm{b}} \pm 19,21}$ & $205,24^{\mathrm{b}} \pm 13,66$ & $196,21^{\mathrm{b}} \pm 11,37$ \\
\hline
\end{tabular}

Keterangan :

P1 : Turiang $100 \%$ + rumput lapang $0 \%$

P3 : Turiang 50\% + rumput lapang 50\%

P2 : Turiang $75 \%+$ rumput lapang $25 \%$

P4 : Turiang $25 \%+$ rumput lapang 75 


\section{Kerapatan}

Kerapatan wafer merupakan suatu ukuran berat pesatuan luas yang salah satunya bergantung pada kerapatan bahan baku penyusunnya. Hasil analisis ragam menunjukkan wafer yang dibuat tidak memberikan pengaruh nyata $(\mathrm{P}>0,05)$ terhadap kerapatan akan tetapi pada uji Duncan terdapat perbedaan pada masing-masing perlakuan. Perlakuan P1 berbeda nyata dengan P3 dan P4, dan tidak berbeda nyata dengan P2.

Nilai kerapatan wafer P1 sampai P4 semakin bertambah. Semakin tinggi nilai kerapatan maka daya simpan wafer akan lebih tahan lama karena bentuk fisiknya yang lebih padat dan keras. Dijelaskan Daud dkk. (2013) bahwa kerapatan wafer yang semakin tinggi diperkirakan akan lebih tahan lama dalam penyimpanan karena bentuk fisiknya yang padat dan keras, selain itu secara fisik juga akan lebih mudah dalam penanganan baik dalam penyimpanan ataupun adanya goncangan pada saat transportasi, begitupun sebaliknya. Dengan kata lain, perlakuan P3 dan P4 memiliki nilai kerapatan yang baik.

Nilai kerapatan berbanding terbalik dengan kadar air. Semakin rendah kadar air maka nilai kerapatan akan semakin meningkat, begitupun sebaliknya. Hal ini sejalan dengan yang dijelaskan pada penelitian Retnani dkk. (2009) dengan semakin meningkatnya kadar air wafer menyebabkan ruangan yang diisi air lebih banyak sehingga kerapatan wafer menurun. Keadaan wafer yang tidak stabil dapat menyebabkan nilai ekonomis bahan akan berkurang karena terjadi pengkerutan atau penyusutan (Frazier dkk., 1979) dengan kata lain kerapatan wafer juga akan menyusut.

Faktor lain yang berpengaruh adalah udara, baik udara kering ataupun lembab. Trisyulianti dkk. (2001) menjelaskan bahwa udara kering atau lembab akan mudah mempengaruhi wafer pakan yang porous dibandingkan wafer yang padat. Hal ini diakibatkan sirkulasi udara di dalam tumpukan wafer yang porous akan lebih lancar dibanding wafer yang padat.

Kerapatan wafer berhubungan dengan palatabilitas ternak. Wafer yang memiliki kerapatan yang tinggi cenderung akan menurunkan palatabilitas ternak. Hal ini diakibatkan oleh wafer yang memiliki kerapatan yang tinggi memiliki tekstur yang lebih padat sehingga ternak akan kesulitan untuk mengkonsumsinya. Hal ini dijelaskan oleh Retnani dkk. (2009) bahwa kerapatan yang tinggi akan menyebabkan sulitnya ternak dalam mengkonsumsi wafer ransum komplit secara langsung.

\section{Daya Serap Air}

Daya serap air wafer merupakan suatu kemampuan wafer dalam mengikat air atau kelembaban yang ada di sekitarnya. Hasil analisis ragam menunjukkan perlakuan memberikan pengaruh nyata $(\mathrm{P}<0,05)$ terhadap daya serap air. Hasil uji Duncan menunjukkan P1 tidak berbeda nyata dengan P2 dan berbeda nyata dengan P3 dan P4. Rataan tertinggi perlakuan P3 dan terendah P1. Persentase daya serap yang dihasilkan sedikit lebih tinggi dibandingkan penelitian yang dilakukan Retnani dkk. (2010) dengan nilai rataan daya serap air 116,87-192,63\%.

Daya serap air berhubungan dengan kadar air yang dihasilkan. Trisyulianti dkk. (2003) menyebutkan bahwa kadar air berbanding terbalik dengan daya serap airnya. Semakin tinggi kerapatan dan kadar air maka kemampuan daya serap air akan semakin rendah. Hal ini sejalan dengan perlakuan P2 dimana kadar airnya memiliki hasil yang tinggi dengan daya serapnya. Begitupun sebaliknya, kadar air perlakuan P4 memiliki nilai terendah, sedangkan daya serap airnya menghasilkan nilai yang tinggi.

Wafer ransum komplit yang memiliki daya serap air yang tinggi akan membuat stabilitas dimensi wafer menjadi lunak dan cepat hancur jika terkena air sehingga disinyalir tidak tahan terhadap penyimpanan dalam kurun waktu yang lama. Umumnya kadar air ransum pakan ternak akan meningkat seiring dengan semakin lamanya waktu penyimpanan (Prabowo, 2003).

Daya ikat air akan berpengaruh terhadap mudah tidaknya wafer dikonsumsi ternak dan lama penyimpanannya. Dijelaskan Krisnan dan Ginting (2009) bahwa daya serap air yang rendah akan menyulitkan dalam pengahancuran bahan atau wafer oleh saliva pada saat dikonsumsi oleh ternak ruminansia, akan tetapi daya serap air yang terlalu tinggi juga akan menyebabkan wafer tidak akan tahan lama untuk disimpan.

\section{Kesimpulan}

Kesimpulan dari hasil pemaparan di atas bahwa turiang padi yang merupakan hasil ikutan generasi kedua dari tanaman padi berpotensi untuk dijadikan sebagai bahan 
pembuatan wafer. Selain memiliki kandungan nutrien yang baik, pemberian turiang padi juga dapat meningkatkan produktivitas ternak. Pembuatan wafer dengan bahan turiang padi dan rumput lapang sebagai bahan utamanya memberikan hasil yang berbeda nyata $(\mathrm{P}<0,05)$ terhadap kualitas fisiknya. Wafer yang menunjukkan hasil rataan yang paling tinggi yaitu wafer dengan komposisi $50 \%$ turiang padi dan $50 \%$ rumput lapang, sedangkan rataan terendah yaitu wafer dengan komposisi $100 \%$ turiang padi. Oleh karena itu dengan adanya penggunaan turiang padi dapat meningkatkan kualitas wafer yang dibuat.

\section{Daftar Pustaka}

AOAC. 1988. Official Methods of Analysis. Association of Official Analytical Chemists. Benjamin Franklin Station, Washington.

Coleman, R.J. dan L.M. Lawrence. 2000. Alfalfa Cubes for Horses. Department of Animal Sciences; Jimmy C. Henning, Department of Agronomy. University of Kentucky Cooperative Extension Service. Kentucky.

Daud, M., Z. Fuadi, dan Azwis. 2013. Uji Fisik dan Daya Simpan Wafer Ransum Komplit Berbasis Kulit Buah Kakao. Jurnal Ilmiah Peternakan, 1 (1) : 20-22.

Frazier, W. C and D. S. Westhoff. 1979. Food Microbiology. Mc. Graw Hill Publishing Co., Ltd. New Delhi.

Kamus Besar Bahasa Indonesia. 2019. Badan Pengembangan dan Pembinaan Bahasa, Kemendikbud : Turiang (Online). Melalui : https://kbbi.web.id/turiang. [28 April 2019].

Kling, M dan W. Wohlbier. 1983. Handelsfuttermittel, band 2A. Verlag Eugen Ulmer, Stuttgart.

Krisnan, R. dan S. P. Ginting. 2009. Penggunaan Solid Ex-Decanter sebagai Perekat Pembuatan Pakan Komplit Berbentuk Pelet : Evaluasi Fisik Pakan Komplit Berbentuk Pelet. Seminar Nasional Teknologi Peternakan dan Veteriner 2009 : 480 - 486.

Prabowo, F. D. 2003. Performans Sapi Betina Brahman Cross Yang Diberi Wafer Ransum Komplit Berbahan Baku Jerami. Fakultas Pertanian Institut Pertanian Bogor, Bogor.

Pomeranz, Y. 1974. Biochemical, Functional and Nutritive Changes During Storage.
In : C. M. Christensen (ed). Storage of Cereal Chemist, St. Paul, Minnesota.

Retnani, Y., S. Basymeleh, dan L. Herawati. 2009. Pengaruh Jenis Hijauan Pakan dan Lama Penyimpanan terhadap Sifat Fisik Wafer. Jurnal Ilmiah Ilmu-ilmu Peternakan, 12 (4) : 200.

Retnani, Y., Widiarti, W., Amiroh, I. Herawati, L., Satoto, K.B. 2009. Daya Simpan dan Palatabilitas Wafer Ransum Komplit Pucuk dan Ampas Tebu untuk Sapi Pedet. Prosiding Media Peternakan : 130-136.

Retnani, Y., N. Furqaanida, R. G. Pratasdan M. N. Rofiq. 2010. Pemanfaatan Klobot Jagung Sebagai Wafer Ransum Komplit untuk Domba. Majalah Ilmiah Peternakan. Vol 13 (1): 1-11.

Sondhy Kamesworo. 2010. Pemberian Wafer Limbah Sayuran Pasar terhadap Konsumsi, Pertambahan Bobot Badan dan Konversi Pakan Ternak Domba. Institut Pertanian Bogor. Bogor.

Suadnyana, I.W. 1998. Pengaruh Kandungan Air dan Ukuran Partikel terhadap Perubahan Sifat Fisik Pakan Lokal Sumber Protein. Fakultas Peternakan. Institut Pertanian Bogor. Bogor.

Trisyulianti, E. 1998. Pembuatan Wafer Rumput Gajah untuk Pakan Ruminansia Besar. Seminar Hasil- hasil Penelitian Institut Pertanian Bogor. Jurusan Ilmu Nutrisi dan Makanan Ternak. Fakultas Peternakan. Institut Pertanian Bogor. Bogor.

Trisyulianti, E. J. Jacja dan Jayusmar. 2001. Pengaruh Suhu dan Tekanan Pengempaan terhadap Sifat Fisik Wafer Ransum Dari Limbah Pertanian Sumber Serat dan Leguminosa untuk Ternak Ruminansia. Media Peternakan, 24 (3) : 77.

Trisyulianti, E., Suryahadi, Rakhma V.N. 2003. Pengaruh Penggunaan Molases dan Tepung Gaplek sebagai Bahan Perekat terhadap Sifat Fisik Wafer Ransum Komplit. Media Peternakan, 26 (2) : 3539. 